Bangladesh Journal of Bioethics 2013; 4(1):9-19

\title{
PEACE, CONFLICT AND RESOLUTION (GOOD VS. EVIL)
}

\author{
Arif Hossain \\ Vice-President \& Founding Chairman \\ Bangladesh Bioethics Society \\ Email: ahossainbbs@gmail.com
}

ABSTRACT: The immense structural inequalities of the global social /political economy can no longer be contained through consensual mechanisms of state control. The ruling classes have lost legitimacy; we are witnessing a breakdown of ruling-class hegemony on a world scale. There is good and evil among mankind; thus it necessitates the conflict between the good and evil on Earth. We are in for a period of major conflicts and great upheavals. It's generally regarded that Mencius (c.371c.289 B.C) a student of Confucianism developed his entire philosophy from two basic propositions: the first, that Man's original nature is good; and the second, that Man's original nature becomes evil when his wishes are not fulfilled. What is good and what is evil? Philosophers of all ages have thought over this question. Each reckoned that he had solved the question once and for all, yet within a few years the problem would re-emerge with new dimensions. Repeated acts of corruption and evil action makes a man corrupt and takes away a man from his original nature. Still now majority of the people of the world give compliance to corruption because of social pressures, economic pressures, cultural pressures and political pressures. The conflict between good and evil is ancient on earth and is prevalent to this day. May be the final confrontation between the descendants of Cain and Abel is at our doorsteps. During the $2^{\text {nd }}$ World War America with its European allies went into world wide military campaign to defeat Germany, Italy and Japan. When the Second World War ended in 1945 the United States of America came out as victorious. America was the first country to detonate atomic bomb in another country. During that period Russia fell into competition with America in politically colonizing countries after countries. With the fall of Communism Russia terminated its desire wanting to be the champion of the oppressed of the world. The situation in Russia continues to deteriorate, a country which until only a few years ago was a superpower. Russians are deeply disillusioned today with the new politicians in Russia, who they says "promise everything and give nothing." The Russians still strongly oppose a world order dominated by the United States. If anyone looks at or investigates the situations in other countries it can be seen that at present almost all countries of the world are similar or same in the forms of structures of corruption and evil. The Worldwide control of humanity's economic, social and political activities is under the helm of US corporate and military power. The US has established its control over 191 governments which are members of the United Nations. The last head of state of the former Soviet Union, Mikhail Gorbachev on December 2012, at a conference on the future of the Middle East and the Black Sea region in the Turkish city of Istanbul, has warned the US of an imminent Soviet-like collapse if Washington persists with its hegemonic policies. Mass public protest occurred against US hegemony are mainly from Muslim countries of South East Asia, South Asia, Central Asia, West Asia, North Africa and Africa. The latest mass protests erupted in September 2012 when the divine Prophet Muhammad (pbuh) was insulted by America and Israel. There were strong mass protests by people from Indonesia to Morocco and in the European countries by mostly immigrants and Australia were there are Muslim populations. This worldwide protest had occurred while the rise of the masses is ongoing against corrupt rulers in West Asia and North Africa. The masses of the people are thirsty and desperate for justice, dignity, economic welfare and human rights. Most major religions have their own sources of information on the Last Age of Mankind or the End of Times, which often include fateful battles between the forces of good and evil and cataclysmic natural disasters. Humans are evolving to a final stage of their evolution towards a 'New Age' that is to come which the corrupt does not understand. At present times a final battle of good versus evil on Earth will ensue. The World powers (leaders) and their entourages who are really detached from the masses have organized to keep aloft the present world order that degenerates the masses in corruption, keeps the people in unhappiness, and deprives the 
masses from economic well being, education and keeps promoting wars and conflicts to support corruption and evil. We are at the "End of Times". The Promised Messiah will come to set right what is wrong, no doubt.

INTRODUCTION: At the beginning of the second half decade of this century states and ruling classes are unable to hold back the tide of worldwide popular rebellion and resorting to ever more generalized repression. As the crisis of global capitalism spirals out of control, the powers in the global system appear to be unable to propose viable solutions. The immense structural inequalities of the global social /political economy can no longer be contained through consensual mechanisms of state control. The ruling classes have lost legitimacy; we are witnessing a breakdown of ruling-class hegemony on a world scale. There is the concentration of wealth in fewer and fewer hands. Corruption has penetrated every spectrum of society and in governments of all countries. Humans are being choked by their rulers everywhere. People are losing security and are being threatened everyday by the corrupt systems of their own countries. Today with a global population of 7 billion conflicts and upheaval are showing at unprecedented levels. There is a global battle raging between the corrupt and those who want to break free from corruption (Good vs. Evil). The World is sinking deeper into chaos. Global elites cannot manage the explosive contradictions in societies. Global elites are confused, reactive, and sinking into the quagmire of their own making. There is unprecedented concentration of control over the mass media and thought control. The global elites are unable to come up with solutions. They appear to be politically bankrupt and impotent to steer the course of events unfolding before them. Humans are evolving to a final stage of their evolution towards a 'New Age' that is to come which the corrupt does not understand. There is good and evil among mankind; thus it necessitates the conflict between the good and evil on Earth. We are in for a period of major conflicts and great upheavals. Global rebellion of the masses is a doorstep away and is already taking place in major parts of the World. The "empire of global capital" is definitely not sitting idle. As global elites regroup and assess the threat of mass global revolution, they will - and have already begun to - organize coordinated mass repression, new wars and interventions to restore global hegemony. The subtle battle of good versus evil has been waged since the earliest times. At present times a final battle of good versus evil on Earth will ensue

\section{PART 1.}

VIEWS OF PHILOSOPHERS ON HUMANS (GOOD AND EVIL): Chinese philosophy consists of two schools of thought: Confucianism and Taoism. The question of human nature, however, is almost entirely sprung from the Confucian school. It's generally regarded that Mencius (c.371-c.289 B.C) a student of Confucianism developed his entire philosophy from two basic propositions: the first, that Man's original nature is good; and the second, that Man's original nature becomes evil when his wishes are not fulfilled.

'If you let people follow their feelings (original feelings), they will be able to do good. This is what is meant by the saying that human nature is good. If a man does evil, it's not the fault of his natural endowment'

All men, according to Mencius, have a mind which cannot bear to see the suffering of others. For example, if you suddenly see a child about to fall into a well, your first reaction is to save him. You don't do this for the sake of befriending the child's parent or to gain praise from the public; you do it out of your original good nature. According to Lau: because we are caught off our guard, the case is therefore a true manifestation of our original human nature.

According to R. E. Allinson, in A Hermeneutic Reconstruction of the Child in the Well Example, however, such an example is not intended to prove that all men will actually take some action in such circumstances. What Mencius intends to show in the child-falling-into-the-well example is that all men will at least be moved to compassion by such a sight. It is not an empirical example. It is more of a 
phenomenological one. In other words, all we need to prove the statement is that we carry out some sort of self-examination or thought-experiment. Once we are convinced, that's the proof. We don't need the results of others to confirm our result. That's a case for science.

The way man loses his original good nature is like the trees in a mountain that are being subjected to endless disturbances.

Mencius said, 'The trees of the Niu Mountain were once beautiful. But can the mountain be regarded any longer as beautiful since, being in the borders of a big state, the trees have been hewed down with axes and hatches? Still with the rest given them by the days and nights and the nourishment provided them by the rains and the dew, they were not without buds and sprouts springing forth. But then the cattle and the sheep pastured upon them once and again. That is why the mountain looks so bald. When people see that it is bald, they think that there was never any timber on the mountain. Is this the true nature of the mountain?

Likewise with human nature if a man is constantly subjected to negative influence, his character is bound to be affected accordingly, despite occasional good education. But that is not his true character, or his original nature. His original nature, as Mencius always insists, is good. The evil in him is a result of external influence.

Thus, by nature, man's original nature must be good. Man's original nature becomes evil when his occupation goes against nature. 'Mencius said, 'The nature of man is good; it becomes evil because man destroys his original nature.' There are other Chinese philosophers who disclaim this notion of good and evil.

'What is good and what is evil?'; Philosophers of all ages have thought over this question. Each reckoned that he had solved the question once and for all, yet within a few years the problem would re-emerge with new dimensions. In fact, most of the answers would be later found inadequate or unsatisfactory.

\section{A few basic questions we need to ask ourselves:}

(1) Are good and evil absolute or are they relative to the conditions associated with time and place? Do conditions surrounding a particular situation make an act good and at another time make it evil? Does an act appear to be good in the overall perspective, but when torn away from its environment appear to be evil?

(2) Is the concept of good and evil imbued in the nature of man or has he been given divine guidance? If not, how are good and evil identified? If reason is the only guide, is there some criteria to determine what is good and what is evil?

(3) Can we see good and evil in society? What do we naturally choose good or evil? Do we give compliance to evil because of pressures? Social pressures, economic pressures, cultural pressures, political pressures? Who controls society, who controls the economy, who influences the culture?

(4) If good and evil are independent, do they have the same creator? Or is God the Creator of good alone? If so, who has created evil?

(5) If the knowledge of good and evil is instinctive, there should be uniformity of thought between various nations, religions and groups; but there are vast differences among them in almost every aspect. What are the reasons?

Socrates (470-390 BC): This great Greek Philosopher thought that the most important question before man is the determination of good and evil. According to him, knowledge of good and evil and its criteria are imbued in man and he can differentiate between the two if he desires so. With 
sustained thought and guidance of nature he is in a position to know what is good and what is evil. His well known saying 'O man! Know thyself' also points to the fact that the basic principles of good and evil are innate in man and can be discovered by deliberation. Socrates was firmly of the view that there should be basic principles independent of individual desires and beliefs for measuring good and evil and right and wrong.

Plato (428-348 BC): He thought that man is endowed with the knowledge of good and evil before coming to this world. This knowledge existed in his soul but during the period between his creation and his descent in this world, he forgot most of the things. These forgotten things can be recollected either by wise sermons or through meditation on nature. Experience also helps in recollection of the forgotten. All good and evil is innate in man. To Plato, the life of reason and good behavior is a happy life. Good itself is happiness and the soul's paradise.

Aristotle (384-322 BC): He thought that reason is the greatest bounty of God, and called it the 'Divine Spark'. If man uses his reason and other capabilities properly, he can attain self-realization after which he hardly needs any measure for good and evil. The position of self-realization is sufficient for his guidance. Aristotle also considered reason and nature to be sufficient for human guidance. He said that goodness is in harmony with nature and its principles have been set by reason which a wise man can easily find.

Arthur Shopenhauer (1788-1860 AD): This German skeptical philosopher said that man's will to live is his greatest and fundamental desire and the cause of all the struggle in the world. This is the root cause of all evil and suffering. A world where wild desires are struggling with each other, where the more powerful kill and devour the less powerful, is a world of evil; there is no goodness in it. If, however, one, through self-sacrifice, acts sympathetically with others and lives for them, happiness and peace shall prevail in this world.

\section{ORIGIN OF THE CONFLICT OF GOOD AND EVIL ON EARTH:}

Cain and Abel: According to the Book of Genesis, two sons of Adam and Eve. Cain is described as a crop farmer ( a land owner) and his younger brother Abel as a shepherd. Cain was the first human born and the first murderer, and Abel was the first human to die. Cain committed the first murder by killing his brother. By both ancient and modern commentators have typically assumed that the motive was driven by jealousy. Abel's promised wife, Aclima, was more beautiful. Since Cain would not consent to this arrangement, Adam suggested seeking God's blessing by means of a sacrifice. Whomever God blessed, would marry Aclima. When God openly rejected Cain's sacrifice, Cain slew his brother in a fit of jealousy. Abel, the first murder victim, is sometimes seen as the first martyr while Cain, the first murderer, is sometimes seen as an ancestor of evil.

Bible version: Adam knew his wife Eve intimately, and she conceived and gave birth to Cain. She said, "I have had a male child with the Lord's help."

Then she also gave birth to his brother Abel. Now Abel became a shepherd of a flock, but Cain cultivated the land. In the course of time Cain presented some of the land's produce as an offering to the LORD. And Abel also presented [an offering] - some of the firstborn of his flock and their fat portions. The Lord had regard for Abel and his offering, but He did not have regard for Cain and his offering. Cain was furious, and he was downcast.

Then the LORD said to Cain, "Why are you furious? And why are you downcast? ${ }^{7}$ If you do right, won't you be accepted? But if you do not do right, sin is crouching at the door. Its desire is for you, but you must master it."

Cain said to his brother Abel, "Let's go out to the field." And while they were in the field, Cain attacked his brother Abel and killed him. -Genesis 4:1-8 
Repeated acts of corruption and evil action makes a man corrupt and takes away a man from his original nature. This change may take place at an early age and then gradually he mostly or completely moves away from the original nature of man and goes through metamorphosis and becomes something other then human. When a group of individuals collectively becomes corrupt or a majority of a society become corrupt the social structure of the society becomes corrupt and in turn they fail to represent any worthy human values and fails to deliver happiness and peace to society. If a league of nations becomes corrupt they fail to deliver happiness and peace to the world. Still now majority of the people of the world give compliance to corruption because of social pressures, economic pressures, cultural pressures and political pressures. There are planners and architects of evil and corruption in the world and there are voluntary and involuntary followers of evil and corruption in the world. In a family when parents are corrupt the children grows up to be corrupt, there are exceptions. When a government is corrupt the civil and private administration becomes corrupt, in turn the people becomes corrupt. Now, Corruption has entered every levels of society. It's hard to find a few sectors of society where there is clean administration. All developing countries have more or less the same situations related to structure of corruption. In the present age what humans lacks most is humanity.

The conflict between good and evil is ancient on earth and is prevalent to this day. According to the three monotheistic religions we the mankind is the descendants of Cain and Abel. May be the final confrontation between the descendants of Cain and Abel is at our doorsteps.

CURRENT WORLD AFFAIRS: During the $2^{\text {nd }}$ World War America with its European allies went into world wide military campaign to defeat Germany, Italy and Japan. When the Second World War ended in 1945 the United States of America came out as victorious. America was the first country to detonate atomic bomb in another country. During that period Russia fell into competition with America in politically colonizing countries after countries. Although Russia fell way short in influencing the world then what America has accomplished. In the 80's the then Russian President Gorbachev when experimenting with new philosophies for the Soviet Union, Communism collapsed along with all its empire. Now the ideology of Communism rests in the museums of history. With the fall of Communism Russia terminated its desire wanting to be the champion of the oppressed of the world. Now Russia plays more of a role of advocacy politics in world affairs then direct engagements in tension ridden areas and hot spots of the world.

\section{The changes in Russia:}

Organized crime in Russia began in its imperial period of Tsars, but it wasn't until the Soviet era that ("thieves-in-law") emerged as leaders of prison groups in gulags (Soviet prison labor camps), and the Thieves' Code became more defined. After World War II, the death of Joseph Stalin, and the fall of the Soviet Union, more gangs emerged in a flourishing black market, exploiting the unstable governments of the former Republics, and at its highest point, even controlling as much as two-thirds of the Russian economy. In modern times, there are as many as 6,000 different groups, with over 200 of them having a global reach. Criminals of these various groups are either former prison members, corrupt former Communist officials, Russian military members and business leaders, people with ethnic ties, or people from the same region with shared criminal experiences. Also during the 1970s and 1980s, America expanded its immigration policies, allowing Soviet Jews and criminals to enter the country, with most settling in a New York's southern Brooklyn area known as Brighton Beach. Russia was branded as a virtual "mafia state" according to the WikiLeaks cables. There has been a large increase in criminal activity in Israel due to the large influx of Russian-Jews. The Russian Jewish mafia has cooperated with Israeli mafiosi and the Likudist, Labor parties and Kadima parties of Israel. Now most Russian criminal organizations use former KGB agents as hitmen. Following the collapse of communism in the Soviet Union in 1991, the old KGB was replaced by a new, more professional spy agency called the SVR, or the state intelligence bureau. The SVR was modeled after its Western equivalents, the CIA and Britain's MI-6. But in Russia, this reorganization meant that over 200,000 former informers, street detectives and gunmen of the KGB lost their jobs. It is those members of the KGB who the Russian mafia now uses all over the world to carry out "special 
assignments". The new Russia that emerged was not the democratic state which many had hoped for: gangsterism reigns, and corruption and abuse of power have followed the breakdown of social and civil order. The communist system has been overthrown, but the mafia, not the people, became the new rulers. Criminal cartels are believed to control as much as two third of Russia's economy. They run their own banks, they manipulate stock exchanges and the real-estate market and they have managed to turn crime into the only really profitable growth-industry in the post-Soviet era. The situation in Russia continues to deteriorate, a country which until only a few years ago was a superpower. Russians are deeply disillusioned today with the new politicians in Russia, who they says "promise everything and give nothing."

In Russia, anybody can have an ordinary person killed there for 200,400 or 600 dollars. A police chief or a bank director? Perhaps as much as 20,000 dollars. But nothing is impossible. People in Russia say 'You just can't imagine how dangerous it is in Russia today'. No one is safe. Russian mafia has syndicates in China, Vietnam, Thailand, Europe and America. As of 2009, Russian Mafia groups have been said to reach over 50 countries. "A Russian passport? You're in for trouble at every immigration checkpoint in the world. Nobody knows how many Russian gangsters - or prostitutes there are in Vietnam today. The police in Bangkok estimate that there are now large numbers of Russian prostitutes in Thailand, and the numbers are likely to increase the wealthier the country becomes. According to a Bangkok-based diplomat: "There's no shortage of local prostitutes in Bangkok. But rich Thai, Chinese, Japanese and Korean businessmen prefer white girls. It gives them prestige." The Americans, Europeans and Australians visits the prostitutes. The prices they charge US\$ 200-400 as opposed to US\$ 20-30 for a Thai girl - contribute to their special value in terms of social status. Now that China is rediscovering its capitalist past, Russian prostitutes are also back in large numbers in Shanghai. The prostitutes share 50-50 of their income with their mafia bosses. Almost all the girls sends money to their parents in Russia who without that money wouldn't survive a month. These girls are innocent and finding no way to survive they take up this profession. They are wrongly exploited by the corrupt social structures. Many girls are killed as soon as they return to Russia with money which they have saved up in China and elsewhere in the Far East. They are killed for their money and with a "fee" to the gunman which may be as little as US\$ 200 .

The Russians still strongly oppose a world order dominated by the United States. Current Russian foreign policies are motivated by political and economic gains. Still the Russian leader has taken a prudent position against the hegemony of America in the world today. The Russian leader criticized the militant foreign policy of the West, arguing that Russia's repeated warnings went unheeded. Vladimir Putin said in Sept. 2012, "We did warn that prudent action was needed and that it would be wrong to try to achieve anything by force, otherwise chaos would ensue," he said. "And what do we see today? Chaos prevails." To support his argument, Putin recommended Western leaders remember the lessons of history so as not to "destroy Carthage again" in their relations with weak countries. He said, "The Roman Empire not only seized and occupied Carthage, but also destroyed it completely, killed everyone and spilled salt so that nothing could grow there," The Russian leader further noted, "I would hate to see the events witnessed by mankind many centuries ago repeat themselves now," he said. "The strong countries are trying to push their rules and their moral code on weak countries, without taking into account the history, traditions and religion of a particular country."

If anyone looks at or investigates the situations in other countries it can be seen that at present almost all countries of the world are similar or same in the forms of structures of corruption and evil. Is predominance of corruption a permanent structure for societies? All the good actions mankind has taken so far is directly the efforts of men and women everywhere to breakdown the predominant structures of corruptions in societies. The violent and non violent outcries of public protests seen everywhere across the world today are protests to break free from corruption and injustice!

\section{Now few more questions we need to ask ourselves:}

1). Are the governments good and free of corruption and the people are corrupt and the government is trying to teach the people to do away with corruption and evil? 
2). Are the governments corrupt and also the people are corrupt. In turn the corrupt people vote the corrupt governments to rule?

3). Are the government corrupt and the people are good?

4). Are the governments corrupt and the people does not have any way out?

5). Have the people become used to corruption in their daily lives or is it that they are fed up with corruption and evil and trying to break free from it?

6). In what stage of human evolution are we now? Can we determine?

THE ROLE OF THE UNITED STATES IN THE WORLD: The Worldwide control of humanity's economic, social and political activities is under the helm of US corporate and military power. These US sponsored strategies ultimately consist in a process of global subordination.

There are more Americans dependent on the federal government now than ever before in U.S. history. According to the Survey of Income and Program Participation conducted by the U.S. Census, well over 100 million Americans are enrolled in at least one welfare program run by the federal government. Many are enrolled in more than one. That is about a third of the entire population of the country. Sadly, that figure does not even include Social Security or Medicare. The strategies used by capitalist enterprises to increase their rates of profit in recent decades have in general caused great suffering for many workers-higher unemployment and higher inflation, lower living standards, and increased insecurity and stress and exhaustion on the job. Most American workers today work harder and longer for less pay and lower benefits than they did several decades ago.

The Distribution of Wealth in the US and Europe:

In the United States, wealth is highly concentrated in a relatively few hands. As of 2010 , the top $1 \%$ of households (the upper class) owned $35.4 \%$ of all privately held wealth, and the next $19 \%$ (the managerial, professional, and small business stratum) had $53.5 \%$, which means that just $20 \%$ of the people owned a remarkable $89 \%$, leaving only $11 \%$ of the wealth for the bottom $80 \%$ (wage and salary workers).

In terms of types of financial wealth, the top one percent of households have $35 \%$ of all privately held stock, $64.4 \%$ of financial securities, and $62.4 \%$ of business equity. The top ten percent have $81 \%$ to $94 \%$ of stocks, bonds, trust funds, and business equity, and almost $80 \%$ of non-home real estate. Since financial wealth is what counts as far as the control of income-producing assets, we can say that just $10 \%$ of the people own the United States of America.

The United States remains by far the nation with the most wealth, with 101,762 euros $(\$ 130,764)$ per person in stocks, bank accounts and insurance, Allianz researchers said. Some 39 percent of the world's wealth belongs to Americans, while Western Europe accounts for another 31 percent. The gap between rich and poor is still huge. Per capita wealth in the richest countries is still 45 times that of the poorest countries. Women in the United States and Europe have a high total income because on average they are some of the highest paid women in the world. Women living in Yemen and Sierra Leone earn 150 to 250 times less per person then the American and European Women. In recent times, the world's super-rich have taken advantage of corruption to siphon off at least $\$ 21$ trillion, and possibly as much as $\$ 32$ tn, from their home countries and hide it abroad (mostly western countries) a sum larger than the entire American economy. The struggles of the authorities in Egypt to recover the vast sums hidden abroad by Hosni Mubarak, his family and other cronies during his many years in power have provided a striking recent example of the fact that corrupt rulers can use their time to amass immense fortunes while many of their citizens are trapped in poverty. 
According to UNICEF, almost half the world over 3.5 billion people live on less than $\$ 2.50$ a day. At least $80 \%$ of humanity lives on less than $\$ 10$ a day. More than 80 percent of the world's population lives in countries where income differentials are widening. For every $\$ 1$ in aid a developing country receives, over $\$ 25$ is spent on debt repayment. The poorer the country, the more likely it is that debt repayments are being extracted directly from the people who neither contracted the loans nor received any of the money.

\section{Consider the global priorities in spending of wealthy developed countries in 1998:}

\section{Global Priority}

Cosmetics in the United States

Ice cream in Europe

Perfumes in Europe and the United States

Pet foods in Europe and the United States

Business entertainment in Japan

Cigarettes in Europe

Alcoholic drinks in Europe

Narcotics drugs in the world

Military spending in the world
\$U.S. Billions

\section{8}

11

12

17

35

50

105

400

780

\section{The basic social services in all developing countries combined:}

\begin{tabular}{lc}
\multicolumn{1}{c}{ Global Priority } & \$U.S. Billions \\
Basic education for all & 6 \\
Water and sanitation for all & 9 \\
Reproductive health for all women & 12 \\
Basic health and nutrition & 13
\end{tabular}

Race relations in the US: Historical racism continues to be reflected in socio-economic inequality in America. Racial stratification continues to occur in employment, housing, education, lending, and government. Europe has the same race situation; in many cases is in a worse position then America. Most people in the U.S. continue to have some prejudices against other races. In the view of the US Human Rights Network, a network of scores of US civil rights and human rights organizations, "Discrimination permeates all aspects of life in the United States, and extends to all communities of Non American white races." Discrimination against African Americans, Latin Americans, Non American white Immigrants, South Asians, South East Asians and Muslims is widely acknowledged. In America there is a strong belief amongst millions of White people that America's success as a world leader is a result of God's preferential love for White Christians \{The new chosen people\}. In America one of every nine black families has a close relative in prison over aggressive arrests done by US law enforcement. Even though usage of illegal drugs are roughly the same along racial lines, the Drug Policy Alliance Network shows that African Americans constitute 13 percent of drug users, but are 38 percent of people arrested for drug offenses, and 59 percent of those convicted. A new poll found that 64 per cent of voters now believe that relations between American blacks and whites are getting worse. The survey, carried out recently, suggested that relations between whites and Hispanics in the US were even worse. $71 \%$ thought they were getting worse, while $24 \%$ said they were unchanged. 
US military control over the world: The US has established its control over 191 governments which are members of the United Nations. The conquest, occupation and/or otherwise supervision of these various regions of the World are supported by an integrated network of military bases and installations which covers the entire world. All this pertains to the workings of an extensive Empire, the exact dimensions of which are not always easy to ascertain. The US operates and/or controls between 700 and 800 military bases Worldwide. The Earth surface is being conceived as a wide battlefield which can be patrolled or steadfastly supervised from the Bases. The Atlantic Alliance (NATO) has its own Network of military bases, thirty in total. The latter are primarily located in Western Europe. US defense spending (excluding the costs of the Iraq war) have increased from 404 billions in 2001 to 626 billion dollars in 2007 according to data from the Washington based Center for Arms Control and Non-Proliferation. US defense spending was 640 billion dollars in 2008. When the budget was signed into law on October 28, 2009, the final size of the Department of Defense's budget was $\$ 680$ billion. Washington keeps a close eye on countries opposed to US corporate control over their resources. Washington also targets countries where there is popular resistance movements directed against US interests. "The establishment of U.S. military bases should not of course be seen simply in terms of direct military ends. They are always used to promote the economic and political objectives of U.S. capitalism. Demonstrations directed against US military presence has developed in Spain, Ecuador, Italy, Paraguay, Uzbekistan, and Bulgaria and in many other countries. Moreover, other long-term resistance movements directed against US military presence have continued in South Korea, Puerto Rico, Guam, the Philippines, Cuba, Europe, Japan and other locations. The US tends to view the Earth surface as a vast territory to conquer, occupy and exploit. The fact that the US Military split the World up into geographic command units vividly illustrates this underlying geopolitical reality.

Major elements of the conquest and world domination strategy by the US refer to:

\section{1) Keeping all governments of the world under sub-ordination.}

\section{2) The taking over of all natural resources (primary resources and nonrenewable sources of energy).}

\section{3) The control of the world economy and its financial markets.}

By the end of 2008 , the U.S. had spent approximately $\$ 900$ billion in direct costs on the Iraq and Afghanistan Wars. Indirect costs such as interest on the additional debt and incremental costs of caring for the more than 33,000 wounded borne by the Veterans Administration are additional. As of June 2011, the total cost of the wars in Iraq and Afghanistan is approximately $\$ 3.7$ trillion so far. The United States wields more military power related to other nations then what the world has ever known, including Rome at the peak of their empire. The USA's military spending accounted for 41 per cent of the world total military spending in 2011, followed by China with 8.2 per cent, Russia with 4.1\% and the UK and France with 3.6 per cent each. The US defense spending accounts for 45.7 percent of total national spending by the world's 171 governments. This is the given best form of democracy in America we have for the world. All other European countries have more or less the same structures of economy, politics, social relations, race relations and others. Developing countries of the world have worse form of politics, democracy, economy and social structures. Social and moral conditions of people at all levels everywhere are deteriorating and at the lowest. Families are breaking up because of corruption within families. Corruption and evil have infiltrated all level of society in every country of the world. The world today is more in sectarian violence then ever in the history of mankind.

The last head of state of the former Soviet Union, Mikhail Gorbachev on December 2012, at a conference on the future of the Middle East and the Black Sea region in the Turkish city of Istanbul, has warned the US of an imminent Soviet-like collapse if Washington persists with its hegemonic policies. Gorbachev noted that disintegration was the atonement that the former Soviet Union made 
for its mistakes and the same fate awaits the US if Washington continues to repeat similar blunders of aggressions.

RISE OF THE MASSES IN REGIONS OF THE WORLD: On April 24 2010, 100,000 people in Okinawa demonstrated against U.S. bases on the island and against the 50-year old "Japan-U.S. Security Treaty". The main demands of the growing movement in opposition to U.S. military presence in Japan include an end to the 50-year old "security" treaty which permits U.S. bases and the removal of the nearly 100 U.S. military installations throughout the country. The U.S. military occupation of Japan is not only a constant danger and threat to the Japanese people, but to the peoples throughout Asia. On $29^{\text {th }}$ January 2012 protesters marched on the US Embassy in Manila over ongoing negotiations between the Philippine and US Governments on putting more US troops and vessels in the Philippines. In November 2012 South America's largest annual anti-militarization gathering occurred in Columbia in an event drawing thousands to protest a US military school that trains Latin American military leaders in torture techniques. The base is home to the US Army School of the Americas, renamed the Western Hemisphere Institute for Security Cooperation, a training facility that has produced some of Latin America's most notorious killers and continues to be implicated in human rights abuses today.

Mass public protest occurred against US hegemony are mainly from Muslim countries of South East Asia, South Asia, Central Asia, West Asia, North Africa and Africa. The latest mass protests erupted in September 2012 when the divine Prophet Muhammad (pbuh) was insulted by America and Israel. There were strong mass protests by people from Indonesia to Morocco and in the European countries by mostly immigrants and Australia were there are Muslim populations. This worldwide protest had occurred while the rise of the masses is ongoing against corrupt rulers in West Asia and North Africa. Repressive regimes aligned with imperialism have held down the struggle in most countries of the Arab world for decades now. There's no doubt that these current upheavals in the Middle East and North Africa are providing tremendous strength and encouragement to the Palestinian people-and fomenting equally tremendous fear and trepidation in Washington and Tel Aviv. The governments of Middle East and North Africa vehemently violated human rights and reduced to mockery the dignity of the Arab citizen. In brief, the Arab citizen enjoyed neither liberty nor justice. Since Hosni Mubarak assumed office in 1981 he turned Egypt into a family business and instilled corruption in every corner of the country. Momentous changes are taking place in the Arab world. Revolutions have become widespread and their impact has been domestic, regional and global. To the masses no longer is the scary ghost of the tyrants are unchallengeable. The Arab world is undergoing a process of massive transformation, necessitated by profound feelings of many years of humiliating national, regional and international injustices, western-supported corruption and subjugation. Prince Abdulaziz bin Abdullah, the Saudi deputy foreign minister, recently said Gulf Arab states must quash any Arab Spring-inspired unrest or risk threats to their leadership across the oil-rich region. Prince Abdulaziz has said Gulf States "cannot tolerate instability" that could lead to challenges to the Western-allied leaders from Kuwait to Oman.

Geographically the (nation of the east), Iran stands between South Asia and West Asia. In 1981 when the Baathist regime of Saddam imposed an eight year of war on Iran all Arab governments of the Gulf and North Africa (except Syria) banded together who politically and militarily opposed Iran and supported Saddam. America, European Countries, Israel and the Arab regimes joined their ranks with Saddam to thwart the revolution in Iran that stood contrary to the present world order. Then in 1991 America waged war on Iraq, the Arab regimes and Israel rallied behind America and later after some years America again attacked Iraq accusing Saddam of having WMD( weapons of mass destruction), whom they themselves equipped with weaponries. This time US captured Saddam and later killed him, destroyed the Baathist military of Saddam, killed scores of Iraqi civilians, bombed and destroyed the infrastructure of Iraq. Why the US and its allies did away with Saddam and his military is a question may be even today the US regrets to answer as Saddam was Iran's arch enemy and when America and its allies are demonstrating enmity towards Iran and threatening Iran now with war. At present again America, Israel and behind them the European governments are threatening Iran with military strikes and war. With the existing situation in Iran and the world once America, Israel and the 
European governments wages war on Iran that would be the start of 'Armageddon-Apocalypse' (World War 3) in the world.

The masses of people of the world are thirsty and desperate for justice, dignity, economic welfare and human rights. Western style democracies have failed to provide the masses any of that and have deceived the masses with false promises. With western style democracies at present a minority is ruling over the affairs of the world and the majority of the masses remain under privileged. The masses everywhere are fed up with corruption, evil and corrupt rulers. Being a target of corrupt politics, corrupt economy, corrupt morality, corrupt law, corrupt administration, and corrupt religion is the prime violation of Human Rights for all humans. The common cry of humanity is to set the Global order on the right path of justice and peace. We are at the juncture of a new age.

(To be continued in part 2 (The End of Times, Armageddon, Apocalypse or the last Age of Mankind) of 'Peace, Conflict and Resolution (Good vs. Evil)' which is going to be published in June 2013 issue of Bangladesh Journal of Bioethics.

This paper has been dedicated to the MASSES of the WORLD.) 